\title{
A Process for Assessing Wooded Plant Cover by Remote Sensing
}

\author{
Jason D. Afinowicz, ${ }^{1}$ Clyde L. Munster, ${ }^{2}$ Bradford P. Wilcox, ${ }^{3}$ \\ and Ronald E. Lacey ${ }^{4}$
}

\begin{abstract}
Authors are ${ }^{1}$ MS Graduate Student, ${ }^{2}$ Associate Professor, and ${ }^{4}$ Professor, Department of Biological and Agricultural Engineering, Texas AひM University, College Station, TX 77840; and ${ }^{3}$ Professor, Department of Rangeland Ecology and Management, Texas A\&M University, College Station, TX 77840.
\end{abstract}

\begin{abstract}
The ability to map the extent of wooded vegetation cover over large areas using remote sensing is important for managing and assessing rangelands. Currently, applied techniques are inadequate because they 1) do not directly measure the amount of land covered by woody plants and rely on low-resolution images, 2) require considerable training-area data to train a classifier, and 3) describe only a limited number of land cover types. This paper presents an innovative methodology for creating a landcover map that requires little to no traditional, training-area data collection before classification. The procedure combines both high-resolution aerial photography (resampled to $2.5-\mathrm{m}$ pixels) and lower-resolution satellite imagery (30-m pixels) to produce a detailed and easily producible data set. The resulting data set also categorizes regions into a wide variety of land cover types in addition to differing levels of wooded cover. This new methodology was applied to the Upper Guadalupe River watershed in Texas, which is composed of varying amounts of brush cover between herbaceous range and dense cover. Validation by comparison to aerial imagery demonstrated a $74.4 \%$ success rate for all land cover classes. Validation was also performed by ground survey for several brush-covered points and showed a $90.0 \%$ success rate. As a result of the ground survey, modifications to the methodology were recommended to reduce classification errors and improve the process.
\end{abstract}

\section{Resumen}

La capacidad de mapear la cantidad de cobertura de vegetación leñosa en grandes áreas usando sensores remotos es importante para manejar y evaluar los pastizales. Las técnicas actualmente aplicadas son inadecuadas porque ellas 1) no miden directamente la cantidad de terreno cubierto por plantas leñosas y se basan en imágenes de baja resolución, 2) se requiere considerable entrenamiento datos de área para entrenar al clasificador, y 3) describen solo un número limitado de tipos de cobertura del terreno. Este artículo presenta una metodología innovadora para crear mapas de cobertura del terreno que requiere de poco a nada de entrenamiento tradicional en la colección de datos de área antes de la clasificación. El procedimiento combina tanto fotografía aérea de alta resolución (remuestrada a $2.5-\mathrm{m}$ pixeles) e imágenes de satélite de baja resolución (30-m pixeles) para producir un juego de datos detallado y fácilmente de producir. El juego de datos resultante también categoriza regiones dentro de una amplia variedad de tipos de cobertura de terreno, además de diferenciar niveles de cobertura de vegetación leñosa. Esta nueva metodología fue aplicada en la cuenca hidrológica Upper Guadalupe River, localizada en Texas. La cual esta compuesta de cantidades variables de cobertura de arbustos entre pastizal herbáceo y cobertura densa. La validación por comparación con las imágenes aéreas demostró un $74.4 \%$ de tasa de éxito para todas las clases de cobertura de terreno. La validación también se realizó en el terreno mediante el reconocimiento de varios puntos cubiertos de arbustos y mostró un a tasa de éxito del $90.0 \%$. Como resultado del reconocimiento en tierra se recomendaron modificaciones a la metodología para reducir los errores de clasificación y mejorar el proceso.

Key Words: Landsat, aerial photography, woody plant encroachment, rangeland assessment

\section{INTRODUCTION}

The encroachment of woody plants in arid and semiarid rangelands has been widely documented (Humphrey 1958; Archer et al. 1988; Van Auken 2000). Historically, the major stakeholder in managing this process has been the individual landowner (Rollins et al. 1988; Texas Agricultural Extension

Correspondence: Clyde Munster, Department of Biological and Agricultural Engineering, Texas A\&M University, 2117 TAMU, College Station, TX 77840-2117. Email: c-munster@ tamu.edu

Manuscript received 8 November 2003; manuscript accepted 14 November 2004.
Service [TAEX] 1998). Modern interest in brush growth and management, however, has a much greater audience as questions arise over issues such as biodiversity (Dye et al. 1995; Fulbright 1996) and carbon sequestration (Pascala et al. 2001; Jackson et al. 2002). Attention has also been focused on the possibility that the removal of wooded species may result in increased water yield (Owens 1996; Bednarz et al. 2000; Wu et al. 2001). Although evidence documenting the beneficial effects of brush control is not conclusive (Dugas and Mayeux 1991; Wilcox 2002), programs have been implemented to subsidize the process of brush management in hopes of relieving strain on water deficient regions (Texas State Soil and Water Conservation Board [TSSWCB] 2002). 


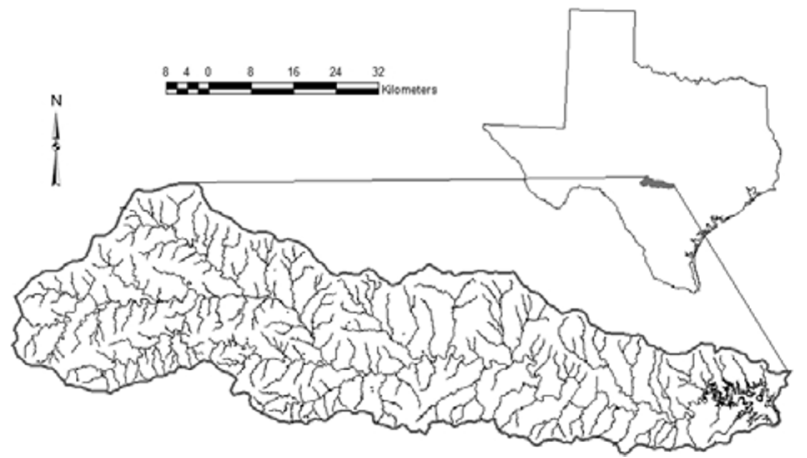

Figure 1. The location of the Upper Guadalupe River watershed and associated stream network in south-central Texas.

Techniques to easily and effectively characterize brush cover over large land areas, such as entire river basins, are needed. Walthall (1982) attempted to quantify the amount of brush cover in western Texas with the use of Landsat Multispectral Scanner (MSS) imagery but could find no distinct correlation between observed reflectance and ground conditions. These difficulties were most likely due to the coarseness of the spatial data used $(60 \mathrm{~m})$. The use of coarse resolution imagery to discern features that are at a scale that is smaller than the pixel size of an image is inherently difficult. Reflectance in a coarse pixel can be subject to a number of qualities such as species diversity and density as well as other biotic and abiotic conditions (Foschi 1994; Hill et al. 1999).

Bednarz et al. (2000) encountered another difficulty when mapping a variety of brush species with Landsat Enhanced Thematic Mapper Plus (ETM+) images in several watersheds throughout Texas. The number of required ground-truth points (over 1000) needed for classifier training was difficult, expensive, and time consuming, even though the method proved to be fairly effective $(70 \%-80 \%$ successful matches).

A different approach to quantifying brush cover was taken by Wu et al. (2001). Aerial photography with a resolution of $1 \mathrm{~m}$ was classified on a basis of wooded and nonwooded pixels. The increased resolution provided better detail of the location and size of individual wooded plants. A moving average window was then used to calculate a focal average of surrounding wooded cover for each pixel. Species information was provided by prior ground surveys of the study area. One problem was the lack of classification beyond rangeland brush types. For hydrologic or similar scientific or management analysis, it is also important to identify urban, agricultural, or water-covered regions. The method used by Wu et al. (2001) may be considered conceptually accurate for discerning levels of brush cover. However, validation of the process was outside the scope of the experiment and was not performed.

This paper proposes methodologies for characterizing brush cover over large regions where 1) scale issues were directly addressed by using data sources of multiple resolutions, 2) field investigation of ground conditions before classification were not required, and 3) all possible land-cover types were included, making the product useful for a variety of purposes.

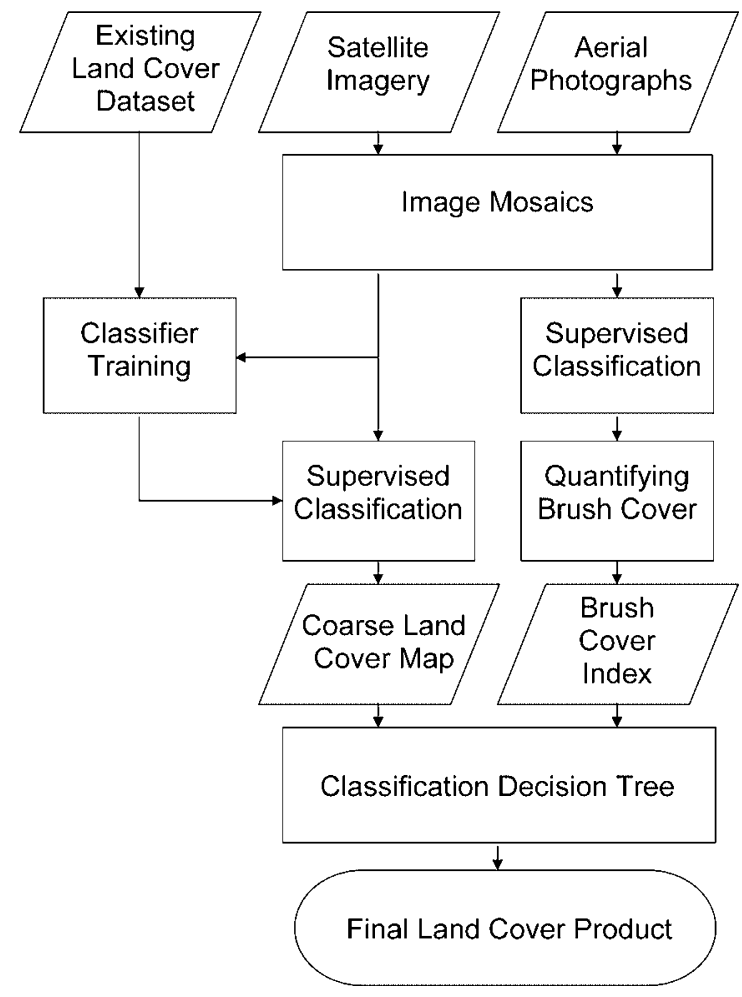

Figure 2. Flow chart of the classification procedure used in the brushcover analysis. The existing National Land Cover Dataset (NLCD), Landsat satellite imagery, and digital orthophoto quadrangle (DOQ) aerial photographs are all used to create the final land-cover product.

\section{METHODS AND MATERIALS}

The watershed chosen for analysis was the Upper Guadalupe River watershed (Fig. 1) on the Edwards Plateau of Central Texas (lat $29^{\circ} 58^{\prime} \mathrm{N}$; long $98^{\circ} 54^{\prime} \mathrm{W}$ ). The $3700-\mathrm{km}^{2}$ watershed empties into Canyon Lake and, eventually, into the Middle Guadalupe River where it provides recharge for the Edwards Aquifer.

Average annual precipitation differs across the watershed, with precipitation levels varying from approximately $900 \mathrm{~mm} \cdot \mathrm{year}^{-1}$ on the eastern edge of the basin to $660 \mathrm{~mm} \cdot \mathrm{year}^{-1}$ on the western side of the watershed. Temperatures range from a January low of $8^{\circ} \mathrm{C}$ to a high monthly mean of $27^{\circ} \mathrm{C}$ in July.

The region is dominated by shallow soils overlaying fractured limestone layers. Typical Eckrant, Tarrant, and Purves soils are often found to be $<1 \mathrm{~m}$ in depth and almost nonexistent around rocky outcrops. The substrate consists of a karst limestone material that is often visible on the surface. Glen Rose limestone layers make up the dominant geology in the lowland areas of the watershed, with Edwards limestone found at higher elevations in the basin (Rose 1972; Texas Bureau of Economic Geology [TX BEG] 1982, 1986). Elevation varies dramatically and creates a terrain of steep rocky slopes and rolling hills for the majority of the basin.

Land cover is predominately rangelands with varying levels of wooded and herbaceous species and shallow soil layers. Woody species include live oak (Quercus virginiana Mill) and Ashe juniper (Juniperus ashei Bucholz). Topography, land cover, and soil depth encourages ranching rather than farming as the dominant agricultural land use except in deeper soils that are often found adjacent to streams. 
Land-cover characterization was carried out by developing a coarse land-cover map and a brush-cover index that was combined into one final land-cover map (Fig. 2). The coarse land-cover map was produced from existing land-cover database and satellite imagery that both provided information at a 30-m spatial resolution. A brush-cover index was then created from 1-m aerial photographs to enhance the coarse land-cover product.

Creation of the coarse land-cover product used selected Landsat ETM+ scenes of the watershed. One image from Landsat path 27, row 39, dated 20 October 1999, and one from path 28, row 39, dated 14 December 1999, were selected from the Texas Natural Resources Information Service (TNRIS) database. These images were then color-balanced and mosaicked to produce one complete image of the basin.

An existing land-cover data set was required to identify regions for collecting spectral signatures to perform a supervised classification. The National Land Cover Dataset (NLCD) provided by the Multi-Resolution Land Characteristics (MRLC) Consortium was chosen because of its demonstrated accuracy (Yang et al. 2001). The use of NLCD data to represent general types of land use was considered reasonable for this study because of the previously established accuracy levels. By overlaying the NLCD land-cover raster with the mosaicked Landsat images, spectral signatures were obtained for all of the cover classes provided by the data set. These signatures, with the exception of classes for "perennial ice/snow," "mixed forest," "orchards and vineyards," and "wetlands," which were either not present or represented a minimal amount of cover, were used to train a Bayesian classifier. This classifier is a modification of the maximum-likelihood parametric classifier in the ERDAS Imagine software package, which uses band covariance for assigning pixels to its most probable classification (ERDAS 1999). The Bayesian method varies this rule by assigning weighted probabilities to classes to prevent unlikely classes from being chosen for a pixel (ERDAS 1999). This capability is helpful to a study in which 1 of 2 spectrally similar classes is more prevalent than the other. For instance, in a rangeland study, a weighted-decision rule allows a disputed pixel to be placed in a more likely class such as "bare soil" rather than in a less likely class of "high-intensity residential."

The output land-cover set was clumped on a basis of 4 similar neighbors. Pixels that were not neighbored on the top, bottom, or either side by at least 1 pixel of the same classification were removed as erroneous matches. These "holes" in the land-cover product were then filled by an elimination algorithm that filled the erroneous pixels with a more likely class determined from the surrounding pixels (ERDAS 1999). This process was used to produce a more contiguous and sensible land-cover map.

Bayesian weights were adjusted several times until the results produced were reasonable when compared with the original NLCD product, the Landsat images, and aerial photography. Final weights for "low-intensity residential," "high-intensity residential," and "commercial/industrial/transportation" were adjusted to a value of 0.2 to reduce a "speckling" in unlikely locations. The weight for "water" was adjusted to 0.4 for similar reasons.

Following classification, the Level II or more detailed classes were combined into Level I or more broadly defined categories to reduce the detail for classes, such as developed and agricultural lands, that were not within the scope of this article. Additionally, several classes were lumped together into a "general range" category that would later be partitioned by the amount of wooded cover observed. This new class was made up of "deciduous forest," "evergreen forest," "shrub land," and "grasslands/herbaceous," as they are described by the NLCD data set.

The final product was an updated, coarse land-cover map that provided the information of the NLCD layer contemporary to the 1999 Landsat images rather than the pre-1992 data used for creating the original database. Additionally, it provided the potential locations of all types of rangeland, from open herbaceous to densely wooded areas. This information was later used in conjunction with aerial image sources for further analysis.

Appropriate high-resolution data sets were selected to develop the brush-cover index. Digital orthophoto quadrangles (DOQs) were obtained from TNRIS in the form of colorbalanced, county-wide mosaics. These inexpensive and readily available electronic near-infrared (NIR) color-composite aerial images provide complete $1-\mathrm{m}$ resolution coverage of the watershed, making them ideal for observing the location and density of wooded plants. In the case of the Upper Guadalupe River watershed, these images were acquired in the early months of 1995, making them reasonably consistent with the chosen Landsat images and recent enough to be useful for study.

After preprocessing of the DOQs by combining the necessary county mosaics and then degrading them to a resolution of $2.5 \mathrm{~m}$ to enhance computation speed, the classification process was carried out as described for the coarse map; however, no preexisting data were available for recognizing brush-covered locations. Instead, representative regions of growing brush, dormant brush, and soil were manually selected by visual identification for spectral extraction. Classification was conducted with the maximum-likelihood rule to produce 3 classes: 1) pixels resembling grassland, 2) pixels resembling growing brush, and 3) pixels resembling dormant brush. Unlike the coarse map analysis, no postprocessing was performed to preserve the detail of the wooded and nonwooded classified regions.

Growing and dormant brush classes were combined into 1 class and assigned a value of 100 . Herbaceous pixels were assigned a value of 0 . The image was degraded to produce a raster image whose pixel values ranged from $0 \%-100 \%$. This value represented the percentage of "wooded," $2.5-\mathrm{m}$ pixels in the larger, degraded-pixel window. A variety of window sizes were tried in an effort to provide the most reasonable unit for assessing cover. A small window often had the divisionary effect of describing a few lone shrubs as discrete, heavily wooded points surrounded by herbaceous range, rather than the more appropriate classes of moderately wooded or lightly wooded. On the other hand, an excessively large window had an averaging effect resulting in the misassignment of a heavily wooded region adjacent to a lightly wooded region as a moderately wooded site. A window size of $60 \mathrm{~m}$ was found to be optimal for minimizing these effects. Thresholds were then used to divide the entire image into regions of open range (cover $<5 \%)$, light wooded (5\%-20\% cover), moderate wooded $(20 \%-50 \%$ cover), and heavy wooded (cover greater than $50 \%$ ). Figure 3 shows a representative area from an aerial 


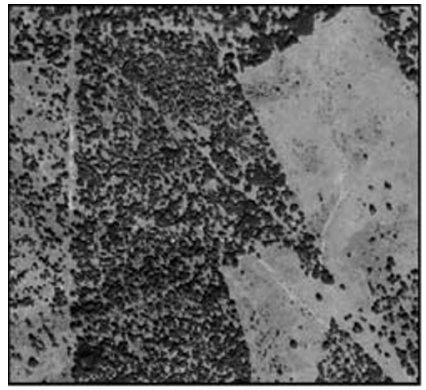

(a)

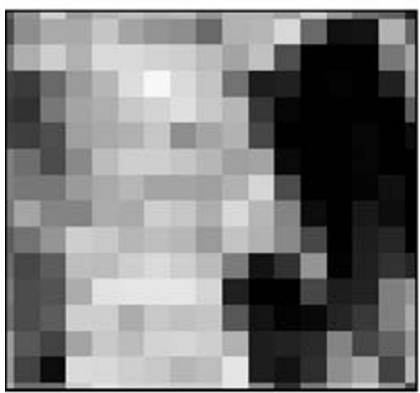

(c)

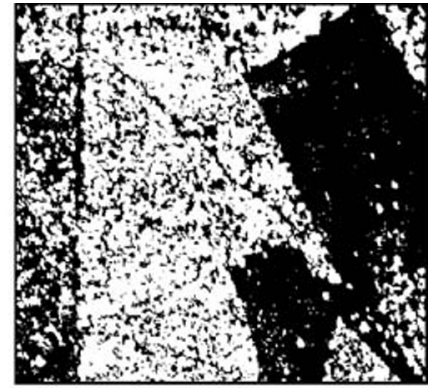

(b)

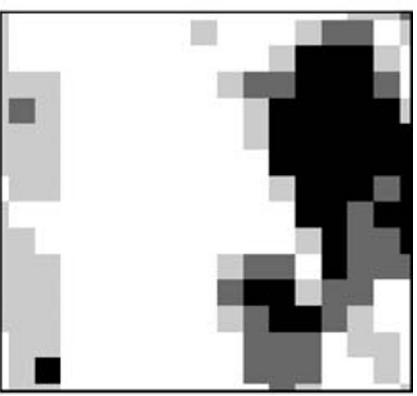

(d)
Figure 3. Four representative images showing the same area a, as viewed from an aerial photograph with a 1-m spatial resolution, $\mathbf{b}$, following classification into wooded and nonwooded pixels, c, after degradation into a $60-\mathrm{m}$ spatial resolution continuous map showing percentage of cover, and $\mathbf{d}$, classified into open range (black) and light (dark gray), moderate (light gray), and heavy brush (white). Regions of various levels of brush cover can be recognized and interpreted in all 4 stages of analysis.

photograph and the same region following classification, degradation, and final classification into the various rangecover classes.

The final map was produced using a decision tree (Fig. 2) to assign the end classes to each $30-\mathrm{m}$ pixel created by the coarse classification process. Each class of a nonrange variety was assigned to the same classification it received in the coarse landcover analysis without regard to the results of the brush-cover index. The tree further classified pixels that were described in the coarse map as either "herbaceous range" or "wooded cover" into heavy, moderate, and light brush or herbaceous range depending on the corresponding data from the brushcover index.

Table 1. Coverage of land classes in the Upper Guadalupe River basin as determined by classification of remote sensing imagery.

\begin{tabular}{lrc}
\hline Land-use Description & Area $\left(\mathrm{km}^{2}\right)$ & Area $(\%)$ \\
\hline Heavy Wooded & 2076.299 & 55.5 \\
Moderate Wooded & 983.085 & 26.3 \\
Light Wooded & 262.629 & 7.0 \\
Agriculture & 141.807 & 3.8 \\
Bare Soil & 106.486 & 2.8 \\
Herbaceous Range & 82.758 & 2.2 \\
Developed & 45.557 & 1.2 \\
Water & 43.615 & 1.2 \\
\hline
\end{tabular}

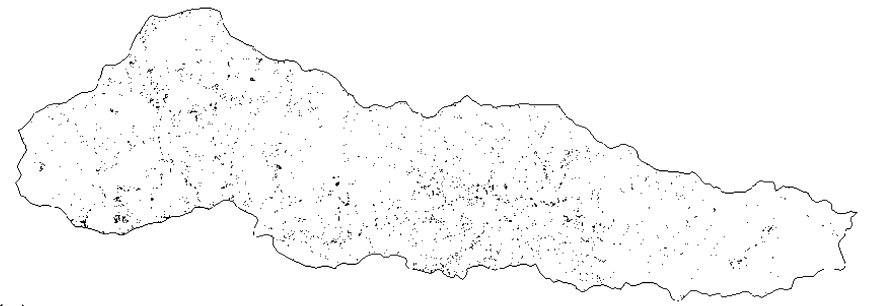

(a)

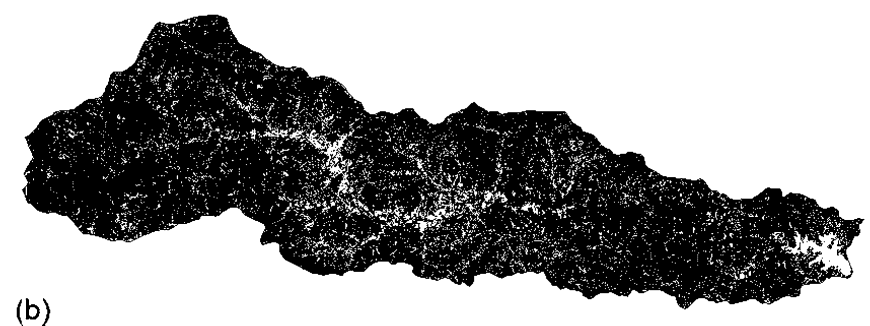

Figure 4. Spatial distribution of $\mathbf{a}$, herbaceous range and $\mathbf{b}$, heavy, moderate, and light brush in the Upper Guadalupe River watershed as determined by remote sensing shown by dark regions.

Two procedures were used to verify the success of the proposed classification method. One method incorporated the use of the original 1-m resolution DOQs to verify the performance of the coarse classification process and the accuracy of the brush-cover index. A multinomial distribution determined that 739 points were required to validate the data set with a confidence interval of $95 \%$ and a precision of $5 \%$. These points were randomly selected throughout the watershed. The results of the classification procedure were visually compared to the aerial imagery with a sample unit of $30-\mathrm{m}$ pixel size (Congalton and Green 1999). An error matrix was produced detailing the rate of success for the classification.

To enhance the aforementioned verification process and to better evaluate the suitability of using aerial and satellite imagery that varied temporally as the Landsat and DOQ images, 20 random points designated as varying levels of rangeland brush cover were selected within the Upper Guadalupe River Watershed that were located within visual range $(20 \mathrm{~m})$ of accessible public roads. Each site was located with the use of a handheld global positioning system (GPS) receiver, visited, photographed, and documented for comparison with the derived land-cover set on a $30-\mathrm{m}$ pixel scale.

\section{RESULTS AND DISCUSSION}

The results of the brush-cover analysis for the Upper Guadalupe River watershed are shown in Table 1. Approximately $88.8 \%$ of the watershed was determined to be covered by various levels of wooded growth. Upon observation, it was easy to determine that heavy-wooded growth (cover $>50 \%$ ) makes up the single largest land-cover class for the basin, covering approximately $55.5 \%$. Moderate brush $(20 \%-50 \%$ cover $)$ was also found to occupy a sizable area $(26.3 \%)$, with light brush (5\%-20\% cover) being the third most prevalent land-cover class, consisting of approximately $7.0 \%$. Pure, herbaceous rangeland accounted for only $2.2 \%$ of the watershed and was actually estimated to cover less area than bare soil and rock 
Table 2. An error matrix produced during the verification of the land-cover product against manually interpreted aerial photographs of the region, dated 1995. Overall accuracy for all classes is shown to be $74.4 \%$.

\begin{tabular}{|c|c|c|c|c|c|c|c|c|c|c|}
\hline \multirow[b]{2}{*}{ Classifed Data } & \multicolumn{8}{|c|}{ Reference Data } & \multirow[b]{2}{*}{ Total } & \multirow[b]{2}{*}{ Percentage } \\
\hline & Water & Developed & $\begin{array}{l}\text { Bare Soil } \\
\text { and Rock }\end{array}$ & $\begin{array}{c}\text { Light } \\
\text { Wooded }\end{array}$ & $\begin{array}{c}\text { Moderate } \\
\text { Wooded }\end{array}$ & $\begin{array}{c}\text { Heavy } \\
\text { Wooded }\end{array}$ & $\begin{array}{c}\text { Herbaceous } \\
\text { Range }\end{array}$ & Agriculture & & \\
\hline Water & 10 & 0 & 0 & 0 & 0 & 1 & 0 & 0 & 11 & $90.9 \%$ \\
\hline Developed & 0 & 3 & 0 & 0 & 0 & 0 & 0 & 0 & 3 & $100.0 \%$ \\
\hline Bare Soil and Rock & 0 & 6 & 4 & 1 & 4 & 4 & 2 & 1 & 22 & $18.2 \%$ \\
\hline Light Wooded & 0 & 0 & 2 & 31 & 5 & 2 & 10 & 0 & 50 & $62.0 \%$ \\
\hline Moderate Wooded & 0 & 2 & 1 & 13 & 132 & 33 & 5 & 4 & 190 & $69.5 \%$ \\
\hline Heavy Wooded & 1 & 3 & 0 & 21 & 38 & 342 & 8 & 5 & 418 & $81.8 \%$ \\
\hline Herbaceous Range & 0 & 0 & 0 & 0 & - & 0 & 10 & 1 & 11 & $90.9 \%$ \\
\hline Agriculture & 0 & 2 & 1 & 3 & 4 & 0 & 6 & 18 & 34 & $52.9 \%$ \\
\hline Total & 11 & 16 & 8 & 69 & 183 & 382 & 41 & 29 & 739 & \\
\hline Percentage & $90.9 \%$ & $18.8 \%$ & $50.0 \%$ & $44.9 \%$ & $72.1 \%$ & $89.5 \%$ & $24.4 \%$ & $62.1 \%$ & & $74.4 \%$ \\
\hline
\end{tabular}

$(2.8 \%)$. Figure 4 highlights the disparity between herbaceous rangeland and the heavy brush-covered area of the Upper Guadalupe River watershed.

Other land-cover classes also made up small portions of the basin area. Developed land covers consisted of $1.2 \%$ of the total watershed, whereas combined agricultural classes ("pasture/hay," "row crops," and "small grains") made up approximately $3.8 \%$ of the region. These values can be considered reasonable, given the nature of the watershed's dominant land use of various rangeland varieties for ranching purposes. Water covered approximately $1.2 \%$ of the watershed and consisted primarily of the surface of Canyon Lake.

\section{Evaluation of Classification Methodology}

The overall accuracy of the proposed methodology was estimated to be $74.4 \%$ by means of comparison to DOQ images (Table 2). The success of classification varied considerably for the various cover classes. For instance, $90 \%-100 \%$ of the random sites identified as water $(90.9 \%$ accurate $)$, devel- oped land (100.0\% accurate), or herbaceous range $(90.9 \%)$ were found to be correctly classified. However, bare soil sites were generally identified incorrectly as one of a number of other classes $(18.2 \%)$. This is likely due to the rocky soils of the area that often allow for minimal ground cover. The high reflectivity of the bare rock may eclipse the signatures of other classes during classification.

Additionally, some critical classes with high-classification accuracies were not correctly identified and classified. For instance, 13 sites that were visually identified as developed land were incorrectly classed as other types, particularly bare soil. This is a significant problem when it is considered that only 16 of the randomly selected sites were identified as developed, meaning that only $18.8 \%$ of the sampled, developed sites were correctly identified.

Greater classification success was achieved for wooded rangeland varieties. Most of the classification errors were among different levels of brush cover, particularly between classes that were on either side of the 5\%,20\%, and $50 \%$

Table 3. Error matrix of the results of a ground survey to verify the classification methodology's sensitivity to various levels of brush cover in the present day. Overall accuracy is shown to be $90.0 \%$.

\begin{tabular}{|c|c|c|c|c|c|c|c|c|c|c|}
\hline \multirow[b]{2}{*}{ Classified Data } & \multicolumn{8}{|c|}{ Reference Data } & \multirow[b]{2}{*}{ Total } & \multirow[b]{2}{*}{ Percentage } \\
\hline & Water & Developed & $\begin{array}{l}\text { Bare Soil } \\
\text { and Rock }\end{array}$ & $\begin{array}{c}\text { Light } \\
\text { Wooded }\end{array}$ & $\begin{array}{c}\text { Moderate } \\
\text { Wooded }\end{array}$ & $\begin{array}{c}\text { Heavy } \\
\text { Wooded }\end{array}$ & $\begin{array}{c}\text { Herbaceous } \\
\text { Range }\end{array}$ & Agriculture & & \\
\hline Water & 0 & 0 & 0 & 0 & 0 & 0 & 0 & 0 & 0 & $N / A^{1}$ \\
\hline Developed & 0 & 0 & 0 & 0 & 0 & 0 & 0 & 0 & 0 & $\mathrm{~N} / \mathrm{A}$ \\
\hline Bare Soil and Rock & 0 & 0 & 0 & 0 & 0 & 0 & 0 & 0 & 0 & N/A \\
\hline Light Wooded & 0 & 0 & 0 & 2 & 0 & 0 & 0 & 0 & 2 & $100.0 \%$ \\
\hline Moderate Wooded & 0 & 0 & 0 & 1 & 3 & 0 & 0 & 0 & 4 & $75.0 \%$ \\
\hline Heavy Wooded & 0 & 1 & 0 & 0 & 0 & 13 & 0 & 0 & 14 & $92.9 \%$ \\
\hline Herbaceous Range & 0 & 0 & 0 & 0 & 0 & 0 & 0 & 0 & 0 & $\mathrm{~N} / \mathrm{A}$ \\
\hline Agriculture & 0 & 0 & 0 & 0 & 0 & 0 & 0 & 0 & 0 & $\mathrm{~N} / \mathrm{A}$ \\
\hline Total & 0 & 1 & 0 & 3 & 3 & 13 & 0 & 0 & 20 & \\
\hline Percentage & $\mathrm{N} / \mathrm{A}$ & $0.0 \%$ & $\mathrm{~N} / \mathrm{A}$ & $66.7 \%$ & $100.0 \%$ & $100.0 \%$ & $\mathrm{~N} / \mathrm{A}$ & $\mathrm{N} / \mathrm{A}$ & & $90.0 \%$ \\
\hline
\end{tabular}

${ }^{1} \mathrm{~N} / \mathrm{A}$ indicates not applicable. 
thresholds. For instance, heavy-brush pixels were most often mistaken for moderate-brush pixels.

Table 3 shows an error matrix detailing the results of the field investigation. An overall accuracy of $90 \%$ was demonstrated, and $100 \%$ of the sites classified as light brush were found to be correct. Accuracies for moderate and heavy wooded sites were $75 \%$ and $92.9 \%$, respectively. Although the verification process showed a higher success rate for classification among the various wooded classes, a few errors recognized during this exercise provided additional information regarding the limitations of the methodology and potential changes that could increase success.

One problem identified in the ground verification process was the misclassification of a site as moderately wooded when it was actually dominated by sparse wooded cover. The site in question (lat $29^{\circ} 58^{\prime} 44^{\prime \prime} \mathrm{N}$, long $98^{\circ} 37^{\prime} 19^{\prime \prime} \mathrm{W}$ ) was composed of a number of small junipers in an even, low-density pattern. This resulted in the classification of the site as a moderately wooded area. This misclassification likely resulted from the $2.5-\mathrm{m}$ pixel size. At this resolution, mixed pixel responses were dominated by the junipers and did not adequately account for the open area between trees. A smaller pixel size may improve classification accuracy; however, increased spatial resolution increases data and processing requirements and makes watershed-level analysis less practical. The results using the previously described methodologies have limitations that must be recognized when working at the watershed scale. Additional analyses, using smaller pixels, can be used to augment the watershedscale analyses when necessary.

Finally, the issue of development throughout this region of Texas (Wilkins et al. 2000) was recognized during a site visit to a location that was classified as heavy wooded cover (lat $29^{\circ} 53^{\prime} 49^{\prime \prime} \mathrm{N}$, long $\left.98^{\circ} 12^{\prime} 14^{\prime \prime} \mathrm{W}\right)$. The site had just recently been cleared for development into a residential community within the previous months. This finding highlights the limitation of using historical data to adequately classify areas of relatively rapid change. Additional and more up-to-date information would help solve this problem; however, data costs can be prohibitive and the data may not be available for the period of interest. This is the same issue faced when low-impact, urban development occurs on sites where tree removal is limited. It would be inefficient to include such areas in a brush management plan, only to remove them at a later stage of the program following ground observation.

The inclusion of additional sources of information into the classification scheme would improve classification results. The availability of GIS data sets concerning current and future land development would improve the remote-classification procedure and minimize modifications to the developed brushmanagement plan.

\section{CONCLUSIONS}

Overall, the procedure returned reasonable results by combining information from 2 different scales, even without the collection of training-area data before classification. The derived product is both easily producible and a potential tool for planning over large regions. Like many remote-sensing techniques, this methodology would be most helpful in studying large regions, such as counties and watersheds that are not easily mapped by conventional methods. Because the methodology focuses on the density of cover, the process would best be used in regions where the variety of cover is relatively homogeneous or is known through other means.

Several observations were made that identify problems in the methodology that may be addressed in the future. With further enhancements to the procedure, accuracy may be increased and produce a more effective tool for studying the effects of woody plant encroachment in the rangeland environment. A few significant observations include: 1) the coarse classifier may require enhancement to more accurately recognize the broad spectrum of land-cover types; and 2) the use of additional data may enhance the ability of the methodology to recognize land use rather than land-cover characteristics. This would produce a significantly more powerful data product for use by planners.

\section{LITERATURE CITED}

Archer, S., C. Scifres, and C. R. Bassham. 1988. Autogenic succession in a subtropical savanna: conversion of grassland to thorn woodland. Ecological Monographs 58(2):111-127.

Bednarz, S. T., T. Dybala, R. S. Muttiah, W. Rosenthal, and W. A. Dugas. 2000. Brush management/water yield feasibility studies for eight watersheds in Texas: Final report to the Texas State Soil and Water Conservation Board. College Station, TX: Texas Water Resources Institute. Report TR-182. 296 p.

Congalton, R. G., and K. Green. 1999. Assessing the accuracy of remotely sensed data: Principles and practices. Boca Raton, FL: CRC Press, Inc. 160 p.

Dugas, W. A., AND H. S. MayeuX. 1991. Evaporation from rangeland with and without honey mesquite. Journal of Range Management 44:161-170.

Dye, K. L., D. N. UeCKeRT, AND S. G. Whisenant. 1995. Redberry juniper-herbaceous understory interactions. Journal of Range Management 48:100-107.

ERDAS 1999. ERDAS field guide. 5th ed. Atlanta, GA: Leica Geosystems. 688 p.

FoschI, P. G. 1994. A geometric approach to a mixed pixel problem: detecting subpixel woody vegetation. Remote Sensing of Environment 50:317-327.

FuLBRIGHT, T. E. 1996. Viewpoint: a theoretical basis for planning woody plant control to maintain species diversity. Journal of Range Management 49:554-559.

Hill, M. J., P. J. Vickery, E. P. Furnival, and G. E. Donald. 1999. Pasture land cover in eastern Australia from NOAA-ACHRR NEDVI and classified Landsat TM. Remote Sensing of Environment 67:32-50.

HumPHREY, R. R. 1958. The desert grassland: a history of vegetational change and an analysis of causes. The Botanical Review 24(4):193-252.

Jackson, R. B., J. L. Banner, E. G. Jobbágy, W. T. Pockman, and D. H. Wall. 2002. Ecosystem carbon loss with woody plant invasion of grasslands. Nature 418: 623-626.

OWENS, M. K. 1996. The role of leaf and canopy-level gas exchange in the replacement of Quercus virginiana (Fagaceae) by Juniperus ashei (Cupressaceae) in semiarid savannas. American Journal of Botany 83:617-623.

Pascala, S. W., G. C. Hurtt, D. Baker, P. Peylin, R. A. Houghton, R. A. Birdsey, L. Heath, E. T. Sundquist, R. F. Stallard, P. Cials, P. Moorcroft, J. P. Casperson, E. Shevliakova, B. Moore, G. Kohlmaier, E. Holland, M. Gloor, M. E. Harmon, S. M. Fan, J. L. Sarmiento, C. L. Goodale, D. Schimel, and C. B. Field. 2001. Consistent land- and atmosphere-based U.S. carbon sink estimates. Science 292:2316-2320.

Rollins, D., F. C. Bryant, D. D. Waid, and L. C. Bradley. 1988. Deer response to brush management in central Texas. Wildlife Society Bulletin 16:277-284.

Rose, P. R. 1972. Edwards group, surface and subsurface, central Texas: Report of investigations. Austin, TX: Texas Bureau of Economic Geology. No. 74. 120 p.

[TAEX] Texas Agricultural Extension Service. 1998. Juniper biology and management in Texas. College Station, TX: TAEX. Publication No. E-54. 10 p.

[TX BEG] Texas Bureau of Economic Geology. 1982. Geologic atlas of Texas, San Antonio sheet. Austin, TX: TX BEG. 
[TX BEG] Texas Bureau of Economic Geology. 1986. Geologic atlas of Texas, Llano sheet. Austin, TX: TX BEG.

[TSSWCB] Texas State Soll and Water Conservation Board. 2002. State brush control plan. Temple, TX: TSSWCB. 53 p.

Van Auken, 0. W. 2000. Shrub invasions of North American semiarid grasslands. Annual Review of Ecology and Systematics 31:197-215.

WALTHALL, C. L. 1982. A study of rangeland brush canopy cover using Landsat Multispectral Scanner data [thesis]. College Station, TX: Texas A\&M University. $85 p$.

WILCOX, B. P. 2002. Shrub control and streamflow on rangelands: a process based viewpoint. Journal of Range Management 55:318-326.
Wilkins, N., R. D. Brown, R. J. Conner, J. Engle, C. Gilliland, A. Hays, R. D. Slack, and D. W. SteInBACH. 2000. Fragmented lands: changing land ownership in Texas. College Station, TX: Texas A\&M University. Technical Report No. MKT3443. $12 \mathrm{p}$.

Wu, X. B., E. J. Redeker, And T. L. Thurow. 2001. Vegetation and water yield dynamics in an Edwards Plateau watershed. Journal of Range Management 54:98-105.

Yang, L., S. V. Stehman, J. H. Smith, and J. D. Wickham. 2001. Thematic accuracy of MRLC land cover for the eastern United States. Remote Sensing Environment 76:418-422. 